\title{
Az eurózóna (lehetséges) szétesésének értelmezései az államközpontú elméletekben
}

\author{
BENCZES ISTVÁN
}

Az eurózóna válsága, a grexit lehetősége, a brexit ténye, vagy éppen az Európaszkeptikus pártok erösödése szerte az unióban arra kell, hogy figyelmeztessenek: az európai integráció immáron nem egy-, hanem kétirányú folyamat. Ennek ellenére a diskurzusnak ma még alig része a dezintegráció és így nem is alakultak ki e folyamat értelmezésének elméleti, fogalmi és módszertani keretei. A cikk a nemzetközi kapcsolatok, valamint az integrációelméletek ún. államközpontú elméleteinek perspektívájából vizsgálja a dezintegrációt. Azt vizsgálja, hogy a neorealizmus, a klasszikus kormányköziség, a neoliberális institucionalizmus, valamint a liberális kormányköziség használható megközelitések-e a dezintegráció (pontosabban az eurózóna dezintegrációja) értelmezésében, segítségünkre vannak-e egy ilyen rendszerszintü folyamat megértésében. A cikk fö megállapítása, hogy az államközpontú elméletek leginkább a tagállamok közötti törésvonalak és alkuk magyarázatában segithetik az érdeklödöt, középpontba állitva mindazon elosztási konfliktusokat, amelyek korábban nem vagy csak másodlagosan voltakjelen az európai (gazdasági) integrációban. Journal of Economic Literature (JEL) kód: F15.

Az integrációelméletek a regionális együttmüködések - így kiemelten az Európai Unió - kialakulását és fejlődését magyarázzák. Jellemzően nem foglalkoznak a dezintegráció kérdéskörével. Ugyan nem állítják, hogy a fejlődés mindenkor egyenes vonalú volna, ahogy a legtöbb ilyen elmélet szerint sem halad az integráció valamiféle végpont felé, ám a szétesést magát külön nem tárgyalják. Holott, mint Cohen [2008, 180. o.] aláhúzza: „...a szuverén államok világában semmi sem tekinthető teljességgel visszafordíthatatlannak".

\section{https://doi.org/10.47630/KULG.2018.62.7-8.4}

Benczes István, egyetemi tanár, BCE Világgazdasági Intézet.

E-mail: istvan.benczes@uni-corvinus.hu 
Az eurózóna (lehetséges) szétesésének értelmezései az államközpontú...

Mint Vollaard [2018, 3. o.] kritikusan megjegyzi, „....a regionális integráció vagy specifikusabban az európai integráció elméletei csak az integrációra fókuszáltak, nem a dezintegrációra. Az európai integrációt érő számos kihívást tanulmányoznak mostanság, de ezek egyike sem adja az európai dezintegráció magyarázatát”. Az európai integrációt ért kihívásokat, mint a bővítést (heterogenitás fokozódását) vagy az euroszkepticizmus (és vele a populizmus) erősödését alaposan tárgyalja az uniós irodalom, de a dezintegráció nem (volt) téma. Tanulmány tárgya a differenciált integráció (Holzinger-Schimmelfennig, 2012, Vigvári, 2016), de nem a kevesebb integráció. Az EU-tanulmányok elvesznek a részletekben, így például a napi szintü kormányzásban és döntéshozatalban, így észre sem veszik a dezintegrációt, mert nem a nagyképet, a transzformatív erejü történéseket vizsgálják (Vollaard, 2014, 1143. o.).

Alapvető probléma az integrációelméletekkel, hogy többségükben müködésképtelenek „,visszafelé”, így azután a dezintegrációnak, vagy akár csak a sikertelen integrációnak nincsen meg a megfelelő szótára, elméleti és fogalmi kerete, valamint módszertana (Jones, 2018). ${ }^{1}$ Holott a válság kirobbanása óta eltelt közel egy évtized történései, mint a szuverén adósságválságok, a brit népszavazás a kilépésről vagy az EU-ellenes pártok erősödése egyértelmüsítik, hogy az európai integráció kétirányú folyamat.

A dezintegráció többnyire az integráció inverzeként jelenik meg. Vagyis ha „,az európai integrációt folyamatként definiáljuk, akkor a dezintegrációt is folyamatként célszerü értelmezni. Olyan folyamatként, amelyben a korábban egyesült entitások az őket alkotó elemekre esnek szét" (Epple-Anders-Tuntschew, 2016, 5. o.). Az Európai Unió (EU) integrációja mind ez idáig egyenes vonalúnak volt mondható három értelemben is: (1) horizontálisan, mivel nőtt a tagállamok száma, (2) vertikálisan, hiszen erősödtek a szupranacionális szervezetek, és végül (3) szektorálisan is, mivel a közös politikák mind kiterjedtebbé váltak (Webber, 2014, 337. o.). Feje tetejére állítva Webber érvelését - lényegileg ő maga is ezt teszi tanulmányában -, a dezintegráció így egyszerre jelentheti bizonyos tagállamok kilépését (vagy a közös politikákból való tartós kimaradását), a nemzetek feletti szervezetek gyengülését, illetve a tagállami szuverenitás visszaerősödését és a közös politikák szükülését.

A Gazdasági és Monetáris Unió (GMU) vonatkozásában a dezintegráció mint kifejezés többnyire arra a (most még csak feltételezett) helyzetre utal, amelyben az eurózónatagok száma csökken, azaz bizonyos tagállam vagy tagállamok egy csoportja elhagyja a monetáris uniót vagy mások erre kényszerítik őket. De jelenthetné

${ }^{1}$ Az egyik legfigyelemreméltóbb kivétel éppen Jones [2018] kísérlete, aki Myrdal [1956] alapján az integráció és dezintegráció kumulatív oksági elméletét állította fel. 
akár a szupranacionális intézmények, így például az Európai Központ Bank (EKB) mandátumának, feladatkörének szúkítését is. Vagy akár a gazdasági és monetáris unió közös politikái hatókörének korlátozását, ami minimálisan is egyfajta stagnálást, azaz kompromisszumhiányt jelentene a továbblépésre - például a bankunió létrejöttének ellehetetlenítését. E veszélyek, bár reálisak, ám mind ez idáig nem kellett velük szembesülnie az EU-nak.

A cikk a nemzetközi politikai gazdaságtan és az integrációelméletek ún. államközpontú elméleteinek (a neorealizmus, a klasszikus kormányköziség, a neoliberális institucionalizmus, valamint a liberális kormányköziség) felhasználásával elemzi és értékeli az unió (szükebben a gazdasági és monetáris unió) szétesésének eshetőségét, pontosabban azt kérdezi, hogy a vonatkozó megközelítések alapján tudunk-e érvényes állításokat megfogalmazni a dezintegrációról. Az államközpontú elméletek közös vonása, hogy racionális, hasznon maximalizáló szereplöként tekintenek az államra, amely az anarchia viszonyai között hozza meg döntéseit. Preferenciái rögzítettek és maga az integráció nem hat a preferenciaformálásra. A hazai (gazdaság)politikától vagy teljesen eltekintenek, vagy leegyszerüsített tárgyalását adják. A cikk a bevezetőt követő részben a szétesés közgazdasági értelmezéseként az optimális valutaövezetek elméletét hívja segítségül, majd az említett négy államközpontú elmélet perspektívájából elemzi a dezintegrációt. A cikket rövid konklúzió zárja.

\section{Az optimális valutaövezetek elmélete mint referenciapont}

A közgazdasági irodalom természetesen nincs híján útmutatásnak az eurózóna esetleges dezintegrációja vonatkozásában. Az optimális valutaövezetek-elmélet müvelői már az európai egységes valuta bevezetése előtt egyértelmüen rámutattak a vállalkozás strukturális gyengeségeire és így a bukás eshetőségére (Feldstein, 1997). Ám még az optimális valutaövezetek elmélete is inkább azt vizsgálja, hogy melyek azok a feltételek, amelyek között államok egy közössége közös valutát használhat, illetve egy konkrét államnak milyen feltételek megléte esetén érdemes csatlakoznia egy már müködő valutaközösséghez, és nem pedig azt, hogy miért várható egy monetáris unió szétesése.

Az eurózóna válsága visszahozta a korábbi érveléseket a viták fóáramába. Az ún. angolul beszélő közgazdászok köre (Krugman, 2016) most újólag felrótta az európai monetáris architektúra alkotóinak, hogy ami történt, az elörelátható volt - már azok számára természetesen, akik az optimális valutaövezetek elméletét komolyan 
Az eurózóna (lehetséges) szétesésének értelmezései az államközpontú...

vették, és az alapján, vagyis nem politikai, hanem gazdasági érvek mentén értékelték a GMU-projekt válságállóságát. A válságban kiütköztek mindazon rendszerszintủ hibák, amelyek már megalkotásának pillanatában is evidensek voltak - legalábbis a gazdaságelmélet mủvelői számára. Most pedig „,az euró gazdasági csapdává vált, Európa pedig civakodó nemzetek fészke lett", kiszolgáltatva a kontinenst a politikai szélsőségeknek (Krugman, 2013, 7. o.).

A jellemzően az Atlanti-óceán túlpartjáról érkező kritikák gyakorlatilag adottnak vették, hogy rossz a konstrukció és képtelen ellenállni bármilyen komolyabb megrázkódtatásnak, sokknak. „Az amerikaiak hírhedten szkeptikusak az európai monetáris együttműködés hasznosságát illetően" - írta Eichengreen (1996a, 1. o.). A válság ebben a megközelítésben elkerülhetetlen volt. Az angolszász szkepticizmust áttekintő Jonung-Drea [2010] tanulmánya már a címadásával is igyekezett megragadni a korszellemet (az 1989 és 2002 közötti idöszakot): It can't happen. It's a bad idea. It won't last. (Nem történhet meg. Rossz ötlet. Nem lesz tartós.) ${ }^{2}$ A kritikák szerint a valutaunió elképzelhetetlen a fiskális és bankunió nélkül, ezek együttesen adják ki a gazdasági uniót. Sőt, az USA tapasztalatait felhasználva amellett érveltek kritikusai, hogy politikai unió nélkül nem vihető sikerre az európai monetáris unió (Henning-Kessler, 2012). A megoldás e szerint vagy az, hogy a GMU valóban egy teljes politikai unió felé közelít, vagy eleve létre sem jön.

A kritika annyiban jogos, hogy az optimális valutaövezetek endogén elmélete azt feltételezte, hogy a GMU-tagság maga indukál majd intenzívebb kereskedelmet a tagok között, aminek következtében az üzleti ciklusok szinkronitása is erösödik a valutaközösségben (Frankel-Rose, 1998). E - később mind szélesebb körben osztott - felfogás szerint egyáltalán nem probléma, ha az indulásnál a gazdasági szerkezetek és teljesítmények közelről sem azonosak; a heterogenitás nem lehet oka az euróra való átállás elhalasztásának. A közös pénz átvétele ugyanis maga fogja erősíteni a konvergenciát, utólag biztosítva az unió optimális valutaövezet jellegét. Az endogén elméletek azonban nem bizonyultak helytállónak: nem történt meg a remélt konvergencia, sőt több tekintetben is erősödtek a divergenciák (Benczes-Rezessy, 2013).

Azt azonban érdemes hangsúlyozni, hogy az optimális valutaövezetek elmélete eredeti formájában az árfolyamrendszerek közötti választást volt hivatott megkönynyíteni egyfajta költség-haszon elemzés alapon. Európában, a nyolcvanas évek második felében, amikor elkezdődött a monetáris unióról való együtt gondolkodás, már érvényben volt és sikeresen müködött a kiigazíthatóan rögzített európai árfolyam-

2 A cím utalás Dornbusch [2001] írására, amely ebbe a három táborba osztotta az amerikai hozzászólásokat az euró bevezetése kapcsán. 
mechanizmus (ERM). Az EK/EU kontextusában ezért a kérdés inkább úgy merült fel, hogy továbblépjenek-e a tagállamok a rögzítés felöl a közös pénz és a monetáris unió irányába. Ezt azért érdemes kiemelni, mert az optimális valutaövezetek-vitában az egyik központi kérdés éppen az, hogy megéri-e feladni az önálló monetáris politikát azokért az előnyökért, amelyek a rögzítésből vagy az egy pénzre való átállásból származnak. Európa államai az ERM-ben ugyanis nem rendelkeztek autonóm monetáris politikával, kénytelenek voltak a Bundesbank lépéseit követni. ${ }^{3}$

Paradox módon tehát az olyan másodhegedűs államok számára - mint Franciaország vagy Olaszország - az euróra való átállás adhatott lehetőséget a német jegybanktól való közvetlen függés oldására oly módon, hogy a monetáris politikát nemzeti szintről nemzetek feletti szintre delegálták (Grieco, 1996). Az együttmüködés által így nem egyszerüen az antiinflációs politikát, a gazdaságpolitikai hitelességet nyerték a gyengébb felek, hanem megszabadultak a Bundesbank jelentette kötöttségektől is. Mivel biztosítva volt/van részvételük az EKB döntéshozó testületeiben, ezért az uniós monetáris és gazdaságpolitikában is felértékelődik helyzetük. Streeck [2015] hasonlóképpen úgy vélte, hogy a GMU-projekt nem a részt vevő államok szuverenitásának csorbításáról szólt, éppen ellenkezőleg, az érintettek (köztük leginkább Franciaország) így kívánták visszanyerni a Bundesbank fogságába esett pénzügyi szuverenitásukat. A németek pedig saját jól felfogott érdekükből támogatták a projektet (Moravcsik, 2012). Németország gazdasági jólétét a nyitott piacok, a versenyző (tehát nem túlértékelt) valuta és a stabil, inflációmentes pénz garantálhatja. A német gazdasági és kormányzati körök egyetértettek abban (és ez ma sincsen másként), hogy saját érdekeiket és államuk jólétét az garantálja, ha Európa monetáris ügyeit független jegybankok irányítják.

A monetáris politikák autonómiájának kérdését azért is érdemes kihangsúlyozni, mert például a grexit kapcsán kibontakozott vitákban többen is azért érveltek Görögország kiválása mellett, hogy ezzel az ország visszanyerhesse monetáris poli-

3 Szélsőségesen élezte ki e dilemmát az árfolyam-mechanizmus 1992-es kudarca, ami egyebek mellett az olasz líra és a brit font távozását, illetve az árfolyam-mechanizmus lebegési sávjának jelentős mértékủ kiszélesítését eredményezte. A szocialista tömb országaiban bekövetkezett fordulat és rendszerváltás lehetővé tette Németország újraegyesítését. A két német állam egyesítése úgy történt, hogy egyfelől a (nyugat-)német márka maradt az egyesült Németország fizetőeszköze, másfelől a szövetségi kormány jelentős mértékü transzfereket biztosított a keleti országrész felzárkóztatására. A fiskális sokkhatás (emelkedő kormányzati transzferek, szubvenciók és közberuházások formájában) arra szorította a német jegybankot, hogy a német márka vásárlóerejének védelme érdekében restriktív monetáris politikát alkalmazzon. A német jegybank megszorító politikája azonban negatív aszimmetrikus sokként hatott az ERM (európai árfolyam-mechanizmus) más országaiban. Az ilyen egyoldalú kiszolgáltatottság akkor múködőképes, ha a horgonyvaluta (jelen esetben a német márka) tulajdonosa képes a közösség érdekeit is szem előtt tartani, ami azonban a nemzeti érdekekkel ellentétes is lehet. 
Az eurózóna (lehetséges) szétesésének értelmezései az államközpontú...

tikájának autonómiáját. És hasonlóképpen: az eurózónától való távolmaradás tipikus érve a nemzeti kézben maradó és így feltételezetten hatékony jegybanki politika.

Több elképzelés is született arról, hogy a görög válság megoldása a GMU-ból való kilépéssel volna megoldható - és egyszersmind az EU-tagság fenntartásával. Feldstein [2010], illetve Rodrik [2010] olyan átmeneti exitben gondolkodtak, ami világos menetrend és játékszabályok szerint alakulna, lehetővé téve a görög gazdaság versenyképességének helyreállítását a nemzeti valuta újbóli bevezetése (és annak leértékelődése) után. A kilépés opciójával úgy élhetne egy bajba jutott ország, hogy azután kötelező volna visszatérése a valutarendszerbe - egy jóval versenyképesebb árfolyamon. Az átmeneti kilépéssel a fiskális konszolidáció költségei is mérséklődnének például azáltal, hogy a magánszektor képes volna - legalább részben - felszívni a közszektorból elbocsátottakat (a közszektor rendbetételének igénye tehát még ezen reformgondolatoknak is része maradt). ${ }^{4}$

Ha Görögország visszatérne a nemzeti fizetőeszközhöz, akkor a valuta leértékelődését követően a kivitel ugyan erösöd(het)ne, de ez önmagában nem jelent tartós megoldást. Több feltételnek is javulnia kell, ha valós eredményt remél egy bajba jutott gazdaság. Az árversenyképesség erősödése nem jelzi a minőségjavulást vagy például közvetlenül a görög termékek népszerüségének növekedését. Ha az árelőny nem jár együtt a termelékenységi tényezők javulásával, akkor a nettó barter cserearány-mutató erősödése ugyan látszólag pozitív változásokra utal, de semmi nem garantálja, hogy tartóssá is válik a változás.

De legalább ennyire súlyos következményei lehetnek annak, hogy a leértékelés az adósságszolgálat költségeit azonnal megemeli, mivel a tartozások euróban denomináltak, míg az állami adóbevételek hazai valutában termelődnek. Hasonlóképpen nehéz helyzetbe kerül a privátszektor is külső adósságai finanszírozásánál. Az exit (még ha többé kevésbé rendezett is), felerősíti a bizonytalanságot. A racionális háztartások, az üzleti szektor és a befektetők menekülni fognak a hazai valutában denominált eszközeikből. Ezen eszközök értékvesztése a vagyonhatás miatt újfent deflációs hatású lesz. A hazai valutától való megszabadulás igénye további nyomás alá helyezi a hazai valutát, így végül a likviditási krízis a pénzügyi rendszer és a gazdaság teljes összeomlásához vezethet. A végén maga az exit löki a bajban lévő gazdaságot a nem teljesítés, az államcsőd felé (Eichengreen, 2010, Győrffy, 2017).

${ }^{4}$ Rodrik [2010] mindazonáltal hangsúlyozta, hogy ő soha sem volt eurószkeptikus, de be kell látni, hogy az EU 2010-ben még nem volt érett arra intézményileg, hogy egy válságot megfelelően tudjon kezelni. 
Természetesen nem elhanyagolhatók azok az extra költségek sem, amelyek például abból fakadnak, hogy bizonytalanná válik, vajon nem lesznek-e követői Görögországnak vagy az éppen aktuálisan válsággal küszködő gazdaságnak. Nem lehet majd tudni, ki lenne a következő kilépő. És azt sem lehet biztosra venni, hogy egy ponton túl esetleg majd nem éppen Németország érzi-e túl nagy kötöttségnek a közös valutát és a vele járó szolidaritási kényszert. A racionális viselkedést feltételező államközpontú megközelítések alapján arra lehet következtetni, hogy az EU legerősebb gazdasága mindaddig támogatni fogja a GMU egyben maradását, amíg az az egységes piac egyben tartását is szolgálja. Ám ha az eurózóna szétesése szélsőséges esetben az egységes piac vívmányait veszélyezteti - mert például államok nemzeti hatáskörben szeretnék szabályozni annak bizonyos szegmenseit, közvetlenül is szolgálva saját nemzeti érdekeiket -, akkor a közös piac jelenlegi legnagyobb haszonélvezője sem maradhat majd tétlen.

Az optimális valutaövezetek elmélete segíthet tehát annak megértésében és számszerüsítésében, hogy a közös valuta feladása és a saját fizetőeszköz bevezetése milyen konkrét hatásokkal járhat. Ám annak eldöntése, hogy egy ország vagy országcsoport végül is feladja-e valutauniós tagságát, elsősorban politikai döntés és csak másodsorban a gazdasági kalkuláció eredője. Az 1930-as évekig, amikor is jelentős intézményi reformok valósultak meg az Egyesült Államokban, elvben az USA is jobban járt volna, ha egyes régiói önálló valutát használnak, mivel a különféle sokkok eltérőképpen érintették az ország bizonyos részeit. Mivel azonban a cél az amerikai állam megteremtése volt, ezért nem számított, hogy gazdasági értelemben költséges volt a dollár használatának általánossá tétele (Rockoff, 2000).

Az a kérdés, hogy bölcs döntés volt-e korábban létrehozni a GMU-t, nem keverendö össze azzal, hogy most, hogy már megvan, megmaradjon-e, vagy megszünjön. Az a tény, hogy az optimális valutaövezetek-elmélet kritériumrendszere alapján a közös valutára való áttérés nem feltétlenül volt jó döntés két évtizeddel ezelött, nem vezethet arra a (téves) következtetésre, hogy most viszont fel kellene számolni - hiszen közben maga a GMU is drámaian átszabta ezen országok múködését, újradefiniálta érdekeiket (Aslett-Caporaso, 2016).

\section{A szétesés államközpontú értelmezései}

Az optimális valutaövezetek elmélete hasznos eszköz annak mérlegelésében, hogy milyen konkrét gazdasági hasznokkal és költségekkel jár valamely ország csat- 
Az eurózóna (lehetséges) szétesésének értelmezései az államközpontú...

lakozása egy monetáris unióhoz. Csakhogy az euróra való átállás soha nem volt és valószínűleg nem is lesz tisztán gazdasági megítélés függvénye. A tagállami szinten jelentkező gazdasági és politikai motivációk együttes megértésében segíthetnek a nemzetközi kapcsolatok és az integrációelméletek ún. államközpontú magyarázatai. Sőt, talán abban is útmutatást kínálhatnak, hogy ugyanezen államoknak miért állhat érdekében a másik irányú folyamat erősítése, vagyis az eurózóna szétesése.

Neorealizmus: kiegyensúlyozás és csapódás

A nemzetközi kapcsolatok máig meghatározó államközpontú elmélete a neorealizmus, amely rendkívüli módon szkeptikus a regionális együttműködésekkel szemben. ${ }^{5}$ „Egyetlen állam sem fogja feláldozni saját érdekeit azért, hogy egy nagyobb közösséget támogasson, veszélyeztetve saját biztonságát, aláásva jólétét, veszélyeztetve jövöjét" (Frankel, 1996, xv. o.). A neorealizmus értelmezésében a nemzetközi politikát a nemzetitől az különbözteti meg, hogy előbbiben van (kell) önsegély, míg utóbbiban nincsen, mert a hatékony állam képes megvédeni saját polgárait. ${ }^{6}$ Az államokon belül az aktorok ezért specializálódhatnak, kialakítva együttmüködésük kereteit és normáit. A nemzetközi színtéren ellenben, felettes hatalom híján, az államok igyekeznek fenntartani függetlenségüket még úgy is, hogy akár autarkiát valósítanak meg. A neorealizmus atyja, Kenneth Waltz kerüli is az államok közötti együttműködés leírására az integráció mint kifejezés használatát, azt kizárólag az államon belüli szereplők együttmunkálkodására tartja fenn. Az államok közötti kapcsolatok szükségszerűen lazábbak, mint az államon belüliek, ezekre az interdependencia kifejezést alkalmazza (Waltz, 1979, 104-105. o.).

Így azután a dezintegráció - mint lehetséges forgatókönyv - a realista iskola képviselői számára nemhogy nem elképzelhetetlen, hanem szinte magától értetődő. A nemzetközi struktúra változása (kétpólusúból a több- vagy az egypólusúba való átmenet) és így a hatalmi képességek eloszlásában beálló torzulások az együtt-

${ }^{5}$ A realizmus a második világháborút követően vált a nemzetközi kapcsolatok elemzésének meghatározó iskolájává. Később, a hetvenes években az elmélet főként módszertani gyengeségei okán veszített súlyából. Az elmélet megújítására Waltz [1979] tett sikeres kísérletet, hozzá köthető a neorealizmus, ami - a megújuló társadalomtudományi kutatások igényeinek megfelelően - elöre definiált (mag) feltevések alapján fogalmazott meg hipotéziseket az államok viselkedésére vonatkozóan.

${ }^{6}$ Anarchiában az államok a túlélésért küzdenek, ebben az önsegélyre támaszkodnak. Az önsegély két forrása a belső képességek fokozása erőforrás-mobilizálás révén (fegyverkezés, illetve állami kapacitások erősítése), valamint a külső partnerekkel történő ( $a d$ hoc) szövetségkötés. „Az önsegély rendszerében a biztonságpolitikai szempontok a politikai érdek alá rendelik a gazdasági hasznokat" (Waltz, 1979, 107. o.). 
működési készségre is hatással vannak, ami végső soron dezintegrációra vezet. Ha a realizmust a waltzi neorealizmusra szükítenénk, akkor a szétesés bizonyos értelemben természetes következtetése egy olyan elméletnek, amely elsősorban annak megértésében jeleskedik, hogy miért nem léteznek stabil normák a világpolitikában, hogy miért nem válnak autonómmá az intézmények, és miért nem képzelhető el egy alkotmányos nemzetközi rezsim létrejötte (Stone, 1994, 449. o.).

A realista tábor az EK/EU-t a hidegháború termékének tekintette. A hidegháború lezárultával ezért a realista elméletek müvelői elsősorban azt várták, hogy az új egy- vagy többpólusú rendszerben az európai államok elsődleges, minden mást, így a jólétet és a prosperitást is maga mögé utasító érdeke a túlélés lesz, amit az önsegély biztosít. Egy ilyen instabil rendszerben - a realista logikának megfelelően - az egyik állam biztonságra törekvése egyben a másik állam fenyegetését is jelenti. Az abszolút nyereségek helyére Európában - csakúgy, mint korábban évszázadokon át - a relatív nyereségek kerülnek, megnehezítve vagy akár ellehetetlenítve az együttmüködést.

Realista körökben általános vélemény volt, hogy a hidegháború végeztével a paradigma feltevéseinek megfelelően ,a nyugati államok kapcsolatai visszatérnek az 1930-as, 1940-es évek mintázataihoz, amelyekben az anarchiából fakadó problémák domináltak: a gazdasági rivalizálás, a biztonsági dilemmák, a fegyverkezési verseny, a hipernacionalizmus, a kiegyensúlyozó szövetségek, és végül a háború fenyegetése" (Deudney-Ikenberry, 1999, 104. o.). A tagállami szuverenitás (illetve visszaszerzésének) igénye természetszerüleg állt helyre a Szovjetunió kiegyensúlyozása szükségességének a hiányában. Nem volt többé értelme a szuverenitás integráció általi szűkítésének Nyugat-Európában (Rosato, 2010). Mivel a realista világban a nemzetközi kooperáció legfőbb célja a biztonsági dilemma kezelése, ezért a megváltozott struktúrában nem feltétlenül van motiváció a korábbi együttmüködés fenntartására, annak költségei ugyanis drámaian megnőhetnek - jósolta John Mearsheimer, a talán legismertebb (offenzív) realista (Mearsheimer, 1990a, b). A racionális államok másféle megoldásokat keresnek, és elfordulnak az EU-tól, teret engedve a kiegyensúlyozatlan multipolaritásnak a kontinensen (Mearsheimer, 2010). Érvelése szerint a növekvő bizonytalanság, az érdekek egymásnak feszülése a kiegyensúlyozás igényéből fakadóan elmélyíti a konfliktust az európai felek között, és így azok visszatérnek a II. világháború előtti ellenséges viszonyokhoz: „,[a]z európai államrendszer fogantatásától kezdve háborúval volt terhelve" (Mearsheimer, 1990a, 11. o.). 
Az eurózóna (lehetséges) szétesésének értelmezései az államközpontú...

Az európai integráció szétesésének gondolata nem új keletủ a realista táborban. A klasszikus realizmus nagy alakja, Hans Morgenthau az európai integrációs folyamatok indulásakor azokat ugyan biztatónak vélte, de egyáltalán nem tartotta kizárhatónak a nemzetállam ideájához és a nacionalizmusokhoz való visszatérést. Ezt az alternatívát röviden „politikai kétségbeesésnek” nevezte el Morgenthau-Thompson [1986].7 De legalább ilyen elgondolkoztatók Waltz szavai, aki szerint „politikai értelemben az európai eset komplikált. Sokan úgy hiszik, hogy az EK olyan messzire jutott az egységesülésben, hogy onnan nem léphet vissza, vagy legfeljebb csak kismértékben. Ez talán igaz, de talán az is igaz, hogy olyan messzire jutott az egységesülésben, hogy tovább már nem is mehet" (Waltz, 1993, 69-70. o.).

A realista világban tehát több okból sem valósulhat meg az együttműködés ( $\mathrm{Col}$ lard-Wexler, 2006). (1) Anarchiában - felsőbb, kényszerítő szerv hiányában - fogolydilemma típusú helyzetek állnak elö, amelyekben a Nash-egyensúlyt a kölcsönösen nem kooperáló magatartás jelenti. (2) A relatív nyereség fontosabb, mint az abszolút, ezért államok még abban az esetben sem lépnek együttmüködésre, ha az számukra (is) jólétnövelő hatású volna. Ráadásul sok esetben nem is ismert előre, hogy pontosan mekkora abszolút és relatív nyereséget hozhat az együttmüködés, ami a döntéshozók diszkontrátáját növeli. (3) A kooperáció fokozza az interdependenciát, kiszolgáltatottá, függővé és sebezhetővé téve a részes államokat. Ami logikus döntés egy országon belül (specializáció, munkamegosztás), az végzetes lehet a nemzetközi kapcsolatokban.

E dilemmák feloldására, vagyis az együttmüködés megvalósítására a realista iskola két lehetséges megoldást kínál: koalíció szervezése a közös ellenféllel szemben, illetve egy olyan hegemón felemelkedése, amely kikényszeríti a kooperációt. Az EU esetében ez azt is jelenti, hogy a vizsgálat fókuszába az unió legerősebb tagállama, Németország kerül. Míg az első esetben Németország kiegyensúlyozását és ezzel egyben a ma ismert EU szétesését, addig a másikban a Németországhoz való csapódás és egy német dominanciájú unió kiépülését vetíti előre az elmélet.

Angela Merkel az eurózóna tagállamainak adósságválsága hajnalán így fogalmazott: „, [h]a az euró összeomlik, akkor az Európát és az Európai Unió ideáját is maga alá fogja temetni” (Merkel, 2010). Az idézet világos üzenetet fogalmaz meg: az euró összeomlása az EU szétesését is elörevetíti. Azon túl, hogy az euró kudarca komoly

${ }^{7}$ De e negatív szcenárió mellett két másikat is lehetségesnek tartott a realista iskola talán legnagyobb alakja. Az ún. ,politikai impotencia” forgatókönyve olyan helyzetre utalt, amelyben az európai államok inaktív külpolitikát folytatnak, míg a „politikai kreativitás” koncepciója olyan aktív Európát vizionált, amely politikai, hadászati és gazdasági egységesítésre törekszik. 
konfliktusokat generál a tagok között, megindul a hibáztatás is, és a legtöbben nyilván Németországot fogják bünbaknak megtenni (Zielonka, 2015, 54. o.). ${ }^{8}$ Egy ilyen forgatókönyvben lesznek majd államok, amelyek Németország kihívóiként tüntetik fel magukat, ellenkoalíciókat szervezve a hatalmi politizálás és kiegyensúlyozás jegyében. Mások csapódni próbálnak majd, végletesen megosztva Európát. Az ilyen ellenséges környezetben virulnak majd a nacionalizmusok, teret nyer a populizmus, sérülhetnek a demokratikus jogok. E folyamatok ellen hathat ugyanakkor Grieco [1995, 1996] módosított realista hipotézise szerint az a tény, hogy az EU tagállamai abból a célból szövetkeztek Németországgal a GMU létrehozására, hogy saját pozícióikat erősíthessék az EU-n belül is és a világban is. Ez a fajta csapódás második legjobb megoldásként is értelmezhető, ami által a gyengébb állam is relatíve nagy haszonra tesz szert. A gyengébb államok nem egyszerủen megfogalmazzák véleményüket, hanem ,tényleges hatást gyakorolnak az együttmüködési megállapodás menetére" (Grieco, 1996, 280. o.). Következésképpen, még ha egy-két kisebb állam elhagyja is a GMU-t, a meghatározó nagyok esetében ez nem reális feltevés, mert nem áll érdekükben a távozás, hiszen azzal egyértelmüen Németországot erősítenék, veszélyeztetve saját egzisztenciájukat is.

De a nemzetközi politikai gazdaságtan realista alapokon megfogalmazott hegemón stabilitás elmélete alapján az sem zárható ki teljességgel, hogy Németország előbb-utóbb hegemónként viselkedik majd a kontinensen. ${ }^{9}$ A hegemón stabilitás realista elmélete az önérdekkövető állami logika alapján egészen más következtetésekre jutott, mint az elmélet liberális ága (Kindleberger, 1973, Keohane, 1984). A realista hegemón ugyanis olyan hatalmat vizionál, amely saját céljainak realizálása érdekében nem retten vissza a kényszer alkalmazásától. Különbség továbbá, hogy míg a liberális elméletben a jóságos hegemón a nemzetközi rendszer stabilitásának és prosperitásának kereteit teremti meg, addig ez esetben a hegemón feladata a rendszer nyitottságának biztosítása. A liberalizált nemzetközi gazdaság természetesen nem önmagáért való. Azon túl, hogy erősíti a hegemón pozícióit, biztosítja a nemzetközi rendszer viszonylagos kiszámíthatóságát és békéjét is (Gilpin, 1987). Németországot éppen ezen az alapon vádolják most többen is: az egységes piac egyben tartásában,

${ }^{8}$ Kundnani [2015] azt feltételezi, hogy a britek kilépésével minden korábbinál nagyobb a valószínüsége annak, hogy a többi tagállam koalícióra lép egymással a németek kiegyensúlyozására. Ilyen ellenkoalíciók formálódtak az adósságválság-rendezés és a migrációs válság kapcsán is (Janning-Möller, 2016).

9 A hegemón stabilitás elmélet realista változatáról lásd: Gilpin [1975], valamint Webb-Krasner [1989]. 
Az eurózóna (lehetséges) szétesésének értelmezései az államközpontú...

a nemzetközi szabadkereskedelem erősítésében érdekelt, miközben nem szolidáris a közösség bajba jutott tagjaival (Beck, 2014, Morisse-Schilbach, 2011).

\section{Klasszikus kormányköziség: visszatérés az államérdekhez}

A klasszikus kormányköziség elmélete az integrációelméletek talán legismertebbjét, a neofunkcionalizmust vette kritika alá a hatvanas években, reflektálva mindazon integrációs kudarcokra, amelyek 1965 és 1966 között Franciaország ún. üres szék politikájához voltak köthetők. A francia nemzeti érdeknek a közösségi érdek elé történő helyezésével az államközpontú elméletek is felértékelődtek az unió fejlödésének magyarázatában.

A realizmussal leginkább rokonítható klasszikus kormányköziség elmélete számára sem (volna) meglepö fejlemény az EU, illetve a GMU dezintegrációja. Már az elmélet fogantatása is alapvetően az integrációs folyamatok lassulásához, illetve egyfajta visszarendeződéshez voltak kapcsolhatók a hatvanas években. Hoffmann [1966] elméletében ugyan nem a struktúra volt a meghatározó magyarázó tényező, ám a nemzeti érdek nála is dominánsan megjelent a magyarázatokban. Hoffmann egyik fontos tétele volt, hogy a külső környezet változása (egy külső sokk) nagyon is eltérő reakciókat vált(hat) ki az érintett államokból nemzeti szinten, ami végső soron dezintegrációhoz vezethet. Másik megfigyelése volt, hogy a nemzetállam olyan erős konstrukció, amelyet a különféle intézmények a szupranacionális elitekkel kiegészülve sem tudnak okafogyottá tenni. Nemcsak de Gaulle üres szék politikája, hanem a hetvenes évek külső sokkjaira adott nagyon is eltérő és nagyon is nemzeti válaszok is alapot adtak tézise megfogalmazására.

Webber [2014] szerint a klasszikus kormányköziség alapján arra következtethetünk, hogy dezintegrációra a francia-német tengely együttműködésének kudarca esetén számíthatunk. A hidegháború évei alatt e „duumvirátus” nem az egyenlő felek munkamegosztását jelentette. Franciaországé volt a politikai és diplomáciai vezető szerep, míg Németországé a követés maradt. A német vezetés ezt azzal az egyértelmủ reménnyel vállalta, hogy országuk idővel visszaszerezheti exportpiacait és megerősítheti jelenlétét Európában, majd pedig megvalósulhat az ország (újra) egyesítése (Paterson, 2012).

Loriaux [1999] annyiban árnyalni igyekezett e képet, hogy Németország és Franciaország között nem egyszerủen egy vezető-követő viszonyrendszer épült ki, hanem e két állam két különböző stratégiát igyekezett megvalósítani az integráció során. Németország geopolitikai internacionalizmusa (a multilaterális intézmények 
iránti elköteleződése) együtt létezett Franciaország geopolitikai kartellizmusával, ami egyszerre jelentett államkapitalista fejlődést, illetve a Szovjetunió és az USA egyként való kiegyensúlyozását. Később, már az egységes piac és a közös valuta sikerére utalva vezette be Pedersen [1998] az együttmüködő hegemónia fogalmát. A két vezető európai hatalom politikai és gazdasági erőforrásainak összeadódásával lehetővé vált a kollektív javak közös előállítása. Az EU 2004-es bővítése után azonban mind nyilvánvalóbb lett, hogy a francia-német tandem vezető szerepének, hegemóniájának fenntartása problematikussá vált (Schild, 2010).

E konfliktus az eurózóna válságkezelésében aztán egyértelmủvé is vált. A Lehmann Brothers csődje utáni 2008. októberi állam- és kormányfői csúcson a vezetők úgy határoztak, hogy minden tagállam maga áll jót saját bankjaiért, mellőzik a közös kimentéseket. A kormányközi megoldások, kormányközi szerződések térnyerése is alátámasztja az intergovernmentalista elméletet. Míg a maastrichti folyamatban nagyon is aktív szerepet játszott a Bizottság, addig a válságrendezésben, különösen annak első szakaszában drámai mértékben leértékelődött az intézmény, és kezdeményező szerepét az Európai Tanács vette át (Fabbrini, 2016, Puetter, 2012). Megerősödtek a kormányfői és államfői alkuk, kifejezésre juttatva a tagállami akaratot, akár a közösségi érdekkel szemben megfogalmazva azt. Ennek egyértelmü példája a bilaterális hitelek mint megoldás a görög válság kezelésében 2010 májusában. A kormányköziség elméletét így nem éri meglepetésként, hogy a tagállamok a válságrendezés során nem a több, hanem a kevesebb nemzetek feletti megoldások felé mozdultak el. A nagyobb fiskális kapacitás vagy különösen a transzferunió létrehozása túlmutat a low politicsen, mivel az közvetlenül is hatást gyakorolna egy tagállam szuverenitására, korlátozva annak nemzeti mozgásterét. A válság fájóan igazolta, hogy a tagállamok szuverenitásvágya és a külső körülmények együttesen olyan irányba terelhetik a folyamatokat, amelyben a tagállami alkuk kiszorítják a nemzetek feletti és kölcsönösen elönyös megoldásokat.

Más perspektívából indulva, gazdaságtörténeti áttekintésében Eichengreen [1996b] is hasonló következtetésekre jutott. Demokratikus, szuverén országok képtelenek tartósan működtetni a rögzített vagy kvázi rögzített árfolyamrendszereket. Polányi [1944/2001] alapján azt mutatta meg, hogy a demokratikus választójog kiterjesztésével szűkül a kormányzati mozgástér; a hatalomban lévők pedig ösztönösen a kisebbik rosszhoz, a rögzített árfolyamrendszer feladásához nyúlnak a belső feszültségek feloldására. Ez azonban megakadályozza őket abban, hogy tartós együttmüködést létesítsenek a nemzetközi pénzügyi rendszerek (például az aranysztenderdrendszer) keretein belül. A GMU keretei között a külső leértékelés nem 
Az eurózóna (lehetséges) szétesésének értelmezései az államközpontú...

lehetséges. Az igazodás egyetlen módja a válsággal sújtott tagállamokban a belső devalválás, ami népszerütlenné teszi a regnáló kormányzatot, előrevetítve bukását. Ennek elkerülése érdekében a tagállami kormányzatok érdekében állhat az eurózóna elhagyása vagy legalábbis az azzal való fenyegetőzés.

A klasszikus kormányköziség értelmezésében tehát az európai integráció lassulása, leállása vagy visszafordulása azt jelenti, hogy a részt vevő racionális felek a továbbiakban úgy ítélik meg, hogy az együttmúködés költségei meghaladják annak remélt hasznait. Hoffmann [1966] elméletében az integráció pusztán eszköz, a regionális kooperáció ezért nem a szupranacionális szintet erősíti, hanem a nemzetállamokat teszi még ellenállóbbá a külső kihívásokkal szemben. Ebben a megközelítésben a dezintegráció olyan következmény, amit az magyaráz, hogy az államok nem remélhetnek pótlólagos hasznokat az együttmúködésből - például koordinált védelmet egy külső sokkal szemben -, ami pedig normális esetben egy valutaövezet optimalitásának feltétele. Ilyen helyzetben az adekvát reakció a tagállami mozgástér erősítése a kollektív cselekvések rovására.

Neoliberális institucionalizmus: közös érdekböl...

A realizmus (vagy különösen a klasszikus kormányköziség) természetesen nem tagadja az együttmüködés lehetőségét - igaz ez még annak szélsőséges formáira is. Waltz [1979] maga is úgy utal az EK létrejöttére, mint ami megmutatta, hogy - adott körülmények között - igenis lehetőség kínálkozik az abszolút nyereségek felértékelődésére és a nyílt érdek-összehangolásra. Ám ez a közös érdek mindig csak addig marad fenn, ameddig a körülmények indokolják azt. A rendszer, vagyis a hatalmi viszonyok változása az érdekazonosság helyébe könnyen lépteti az érdekkonfliktust, felértékelve a relatív nyereségeket.

Az érdekek összhangjából vezeti le az együttműködést a neoliberális institucionalizmus is. Ám a realizmussal ellentétben azok tartósságát feltételezi. E tartósságot pedig a különféle nemzetközi intézmények alapozhatják meg. Robert Keohane, a nemzetközi kapcsolatok institucionalista iskolájának atyja például kifejezetten optimista volt az EU jövőjét illetően. A közös érdekekből levezetve arra jutott, hogy az EK/EU a világgazdaság erős, tartós és meghatározó intézménye marad (Keohane, 1993, 291. o.). Ám a neoliberális institucionalizmus arra is rámutat, hogy az integráció, a mélyülés folyamata mindenkor feltételekhez kötött és esetleges. Ebből a perspektívából nézve az EU megmaradása vagy szétesése elsősorban annak a kérdése, hogy a jövőben is fennmarad-e az a közös érdek, ami összeköti a tagokat (Webber, 
2014). E folyamatban kiemelt fontossággal bír, hogy a meghatározó nagy államok, akárcsak a kormányközi elméletben, támogatják-e az integrációt. A brexit így ez esetben különös jelentőséget kap, hiszen tisztán rámutat, hogy a közös érdek létét egyáltalán nem lehet adottságként kezelni Európában.

A Gazdasági és Monetáris Unió vonatkozásában a közös érdek természetszerüleg sokféle lehet. Az együttmüködés hajtóerői lehetnek egyebek mellett a mérséklődő tranzakciós költségek, az intenzívebbé váló kereskedelem, a mélyülő pénz- és tőkepiacok, a hosszú távú hitelezési lehetőségek felfutása, a gazdaságpolitikai hitelesség elnyerése stb. De a válság azt is nyilvánvalóvá tette, hogy olyan szerkezeti konfliktusok feszítik a GMU-t, amelyeket nem lehet a korábban meglévő eszközökkel orvosolni; a hitelező országok belátására és együttmüködésére van szükség a válság valós okainak kezelésére. A válság, különösen annak aszimmetrikus jellege nyilvánvalóvá tette a relatív hasznok fontosságát, és ezzel együtt felvetette annak lehetőségét, hogy az érdekek nem konvergálnak az unióban. Kérdés ezért, hogy az érdekek divergenciája előrevetíti-e az eurózóna szétesését. A válaszadásban segít ugyan a neoliberális institucionalizmus, de következtetései nem egyértelműek. Egyfelől azt várnánk, hogy a tagok szilárd kiállása az euró mellett, a GMU megújulási képessége, amelyet újabb és újabb intézmények és mechanizmusok jeleznek a válságrendezésben (lásd különösen a bankuniót - Mérö-Piroska, 2017), illetve önmagában az a tény, hogy az euró létezik, és mint ilyen újradefiniálja a tagállami magatartást is, mind azt jelzik, hogy nem kell tartani az eurózóna szétesésétől. Némi túlzással az is állítható, hogy az euró úgy kelhet önálló életre, hogy létezése függetlenné válik attól, hogy aktuálisan kik a zóna tagjai (lásd különösen Keohane [1984] gondolatait a hegemón bukása utáni együttműködés és stabilitás lehetőségeiről). Másfelől a neoliberális institucionalizmus alapján arra is következtethetünk, hogy jelenleg nincsenek meg a túléléshez szükséges intézmények a GMU-ban, pontosabban nem azok az intézmények vannak jelen, amelyek a hatékony és tartós müködés elengedhetetlen feltételei. Ennyiben tehát az iskola osztja az optimális valutaövezetek elméletének szkepticizmusát. Közös érdek hiányában, a válságrendezés összhangot nélkülöző megoldásai okán a zóna lassú, de biztos gyengülése, esetleg szétesése várható ezért.

Az institucionalista elmélet szerint az államok újradefiniálhatják érdekeiket a felállott intézményeik szabályainak és gyakorlatának ismeretében. Az intézmények mint ösztönzőrendszerek megváltoztathatják az államok magatartását (KeohaneNye, 1993). Továbbá az intézmények, hasonlóan a rezsimekhez, az adott struktúrától független, önálló életre kelhetnek (Keohane-Martin, 2003). Az intézményi inertia fogalma arra a helyzetre utal, amelyben az autonómmá váló intézmények olyan 
Az eurózóna (lehetséges) szétesésének értelmezései az államközpontú...

struktúrában is életben maradhatnak, amelyben egyébként létrejöttük kétséges (lett) volna. ${ }^{10}$ Példaként említhető az Európai Unió közös agrárpolitikája, ami egy adott történelmi szituáció (struktúra) körülményei között jött létre és ami e körülmények jelentős változása után is szinte sértetlen maradt, konzerválva a torz agrárszerkezetet és a nem hatékony erőforrás-allokációt.

Az euróra is tekinthetünk úgy, mint ami immáron önálló életre kelt, és bár az alapok kétségesek (ami testet ölt a makrogazdasági egyensúlytalanságokban, a versenyképességi divergenciákban stb.), feladni mégsem fogják a tagállamok, mert egyfelől nagy számban vannak haszonélvezői, támogatói, másfelől a feladás költséges volna (Aslett-Caporaso, 2016). A jelenlegi intézmények ugyan nem optimálisak, ám stabilan beágyazottak, ami a dezintegráció ellen hat. Minden szereplő érzékeli, hogy nem ez az optimális elrendezés, ám az arra való áttérés vagy túl költséges volna, vagy egyszerüen nincs mögötte - jelenleg - közös politikai akarat. De szélsőséges esetben még az is elképzelhető, hogy az eurózónatagok cserélődnek, államok esetleg időnként felfüggesztik tagságukat stb. Az elképzelés már csak azért sem irreális, mert az EU-ban korábban a visszavonhatatlan rögzítés alternatívája nem a lebegtetés, hanem a rögzítés volt - és az ERM II mint árfolyam-mechanizmus ma is él, mint az euróra való áttérés előszobája.

A neoliberális institucionalizmus az intézmények varianciáját engedi meg, adott struktúra mellett többféle, egymással is versengő intézmény épülhet ki. Ebben a megközelítésben az alapvető kérdés, hogy miért éppen az aktuális intézményi forma vált meghatározóvá adott közösségben, illetve miként valósítható meg az egyik - a kevésbé hatékony vagy kevésbé preferált - intézményi pályáról való áttérés a másikra. Vagy ha az útfüggés okán a „forradalmi” változtatásokra nincs is mód, még akkor is lehetséges lépésenként építkezni. Már a közös pénzre való áttérés előtt is hangsúlyosan megjelent azt a gondolat, hogy a GMU számos gyengeséggel, tervezési hiányossággal küzd (Jonung-Drea, 2010). A monetáris politika egyesítése azonban egy tanulási folyamatként is felfogható, amelyben az alkotók folyamatosan reagálnak az aktuális kihívásokra. Bordo-Jonung [2000] azt hangsúlyozzák, hogy a folyamatosan változó, adaptálódó intézményrendszer akár jelentős mértékben is eltérhet majd attól, amit a maastrichti folyamat során az alkotók a tervezőasztalon megálmodtak. A válságkezelés közel évtizedes tapasztalatai visszaigazolják e tételt.

Ám a neoliberális institucionalizmus egy másik értelmezést is megenged. Az iskola fontos felismerése volt, hogy az anarchia viszonyai között az intézményektől

${ }^{10}$ A szervezeti inertia, illetve a reputáció azt eredményezik, hogy az intézmények még akkor is tartósan léteznek, amikor létrejöttük feltételei már nem állnak fenn (Keohane, 1993, 295. o.). 
nem várható, hogy kényszerítő erővel rendelkezzenek. A GMU gyengeségét legfőképpen a szerződésben rögzített szabályainak kikényszeríthetőségének hiánya, illetve a szankcionálás majdnem lehetetlensége jelentette. A maastrichti szerződés (illetve a lisszaboni szerződés) nem rendelkezett arról, hogy az Európai Központi Bankhoz hasonlóan olyan nemzetek felett álló szervezetet hozzon létre az EU, amely akár a tagállami érdekek ellenében is szankcionálhatja a nem teljesítést. Központosított kényszerítő erő, illetve mechanizmus hiányában a feleknek a kölcsönös belátásra kellett hagyatkozniuk. Az institucionalista elmélet szerint ez sem kevés. A reciprocitás logikája és a szemet szemért stratégia ugyanis garancia lehet arra, hogy a részes államok hajlandóak vállalni az együttmüködés költségeit, ami a GMU esetében például a túlköltekezéstől való tartózkodást vagy akár a politikailag népszerütlen megszorítások felvállalást is jelenti. Hosszabb távon ugyanis a közös valutából származó előnyök (mint például a hitelesség) felülmúlják a rövid távú haszonszerzésből remélteket.

Minél kevésbé érvényesül tehát az EU-ban az érdekek összhangja, minél több törésvonal szabdalja a közösséget, minél többször marad büntetlen a szabályszegés, annál nagyobb az esélye a dezintegrációnak. A szétesés azonban nem szükségszerüen hirtelen történik, az sokkal inkább egy lassú eróziós folyamat eredménye lenne az intézményi elmélet szerint. Másfelől az sem elképzelhetetlen, hogy maga a válság (illetve válságok sorozata) hívja életre a felismerést, hogy a gazdasági, politikai vagy akár katonai konfliktusok elkerülése közös érdeke a tagoknak. A megelözés melletti elköteleződést a még mélyebb integráció jelentheti, akár egyértelmű elmozdulás formájában a politikai unió, egy föderális Európa felé.

\section{Liberális kormányköziség: gazdasági érdekböl...}

A liberális kormányköziség is épít az intézmények fontosságára, nem tagadja azok hatékony voltát vagy tartósságát. Sőt, hangoztatja, hogy Európa erőssége egyebek mellett abban rejlik, hogy minden más kontinensnél erősebb elköteleződést mutat a különféle multilaterális és integrációs együttmüködésekben való részvételre. De azt sem felejti el megemlíteni, hogy ezen intézmények léte a tagállami érdekből vezethető le. Azt is állítja, hogy a GMU egyfajta minimalista intézményi szerkezettel jött létre Maastrichtban, ahol a felek a legkisebb közös többszörös elvét követték (Moravcsik, 1998). Ezzel Moravcsik, a liberális kormányköziség szellemi atyja nem minősíteni akarja a GMU-t, pusztán kifejezésre juttatja, hogy elmélete az államokat 
Az eurózóna (lehetséges) szétesésének értelmezései az államközpontú...

tartja döntő tényezőnek, az intézmények és a szupranacionális elitek csak alárendelt szerepet játszanak az integrációs folyamatban.

Következésképpen a liberális kormányköziség nem az intézmények irányából közelítve tartja - egyelőre - valószínütlennek az eurózóna (és az EU) szétesését. A szétesés ellen a társadalmi aktorok preferenciái hatnak, amelyekből összeáll az állami akarat. E megközelítésben az euró sikere elsősorban azon múlik, hogy van-e társadalmi (és elsősorban termelői) támogatottsága a monetáris uniónak. Ha a társadalom meghatározó, befolyással bíró erőinek haszna származik a Gazdasági és Monetáris Unió működéséből, akkor az egyes államok vezetői is támogatni fogják a monetáris együttmüködést. ${ }^{11}$ A GMU vesztesei ráadásul jellemzően alulreprezentáltak a nemzeti és az EU-intézményekben, így nem kell tartani attól, hogy az államok az euró ellen fordulnak (Sadeh-Verdun, 2009).

Abban az esetben roppanhat meg a közös valuta, ha mindazon üzleti és kormányzati körök, amelyek ma hasznot realizálnak az euró használatából, kihátrálnak a projektből (Moravcsik, 2012). Az a strukturális feszültség, ami a tagállamok megosztottságából adódik (azaz ahol adósok állnak szemben hitelezőkkel), könnyen vezethet a támogatottság megrendüléséhez és ezáltal - elöbb vagy utóbb - a közös pénz használatának feladásához. Moravcsik [2012] szerint az ún. északi államoknak hajlandóságot kell mutatniuk mind a válságrendezés, mind pedig a déli államok felzárkóztatásának költségviselésére. Kiegyenlítettebb tehermegosztás nélkül nem várható a GMU fennmaradása. E probléma felismeréséhez azonban az kell, hogy a hitelező országok belássák: az eurózóna válsága több mint közpénzügyi válság, az rendszerszintü.

A liberális kormányköziség tehát egyértelmüen felismeri és azonosítja a törésvonalat az EU-n belül - ami tehát nem az eurót használók és azt nem használók között feszül, hanem az északi és a déli országok, illetve más megközelítésben: a hitelező és az adós államok között. A kapitalizmusok változatai (varieties of capitalism) iskola az észak-európaiak exportalapú, sikeres növekedési modelljét állítja szembe a déli tagállamok kereslethúzta növekedési modelljével, mely utóbbi - az árfolyam-kiigazítás eszköze nélkül - képtelen volt lépést tartani az északiakkal (Hall, 2014). Ez a megkülönböztetés élesen szembeállítja a két csoport céljait és eszközrendszerét, ideértve intézményi infrastruktúráját is. A Németország vezette blokk stabilitási kultú-

${ }^{11}$ A liberális kormányköziség szerint a közös valuta természetesen akár az integrációs együttmüködés csúcsaként is értelmezhető, abból nem szükségszerủen következik a politikai unió mint cél, hiszen az államok minden esetben szuverenitásuk csak akkora hányadáról mondanak le, amely az elérendő célok megvalósításához feltétlenül indokolt. 
rára alapozott megtakarítási magatartása áll szemben a déli államok (túlzott) költési hajlamával. Moravcsik [2012] szerint a válságkezelés sikere és voltaképpen a GMU sorsa azon múlik majd, hogy képesek lesznek-e a felek (az északiak és a déliek) áthidalni a makrogazdasági politikák és elvek szintjén megmutatkozó szakadékot.

Mindazonáltal az eurózónából való kilépés elvi lehetőségét egyáltalán nem utasítja el Moravcsik [2017a]. Sőt, voltaképpen ezt tartaná kívánatosnak bizonyos államok esetében - ahelyett, hogy folyamatos megszorítás-kimentés kombinációval próbálják életben tartani például Görögországot. Ám a kilépés forgatókönyvét ezzel együtt is teljességgel valószínütlennek tartja. A bajba jutott államok esetében az euró feladása jó eséllyel államcsődöt vonna maga után, és nem kizárható a monetáris és pénzügyi rendszer leállása, szétesése sem, mindez hiperinflációval és a nemzetközi pénzpiacokról való kiszorulással nehezítve. De az északi államoknak sem áll(t) érdekében az euró feladása, mert a visszatérés a saját fizetőeszközhöz erős felértékelődést, az export visszaesését, mély és tartós recessziót vetít elöre. Másutt még azt is megkockáztatja, hogy a jelenlegi helyzetben egy euró nélküli EU talán még népszerübb és stabilabb is volna, ám ez nem feltétlenül jelenti azt, hogy az európaiaknak fel kellene adniuk a közös fizetőeszközt, hiszen a hosszú távú előnyök bőven kompenzálhatják a tagokat a jelenben felmerülő költségekért (Moravcsik, 2017b).

Szemben a neofunkcionalisták folyamatos előremozdulást hirdető programjával, Moravcsik [2008] értelmezésében az EU előtt álló valós feladat ezért az elért sikerek konszolidálása. Az EU intézményi felépítményét stabilnak, ellenállónak tartja, ezért nincs is szükség alapvetö alkotmányos változtatásokra; elegendőek a kis, inkrementális, hatékonyságjavító intézkedések, amelyekkel a közösség igazodni tud az éppen aktuális kihívásokhoz. „Az exogén sokkok soha sem kizárhatóak, de a jelenlegi trendek - legyen az tartalmi, intézményi vagy normatív - nem valószínú, hogy destabilizálnák a szervezetet" (Moravcsik, 2008, 157. o.). De már közvetlenül a válságra reagálva sem osztotta azok pesszimizmusát, akik temették az EU-t. Sokkal inkább azt az álláspontot képviselte, hogy a válság megerősíti Európát egy olyan világban, amelyben az interdependencia mind meghatározóbbá válik (Moravcsik, 2009a). Abban jelölve ki a liberális kormányköziség müvelőinek feladatát, hogy megtalálják, pontosan mi is ma Európa - ahelyett, hogy azon gondolkodnának, merre halad Európa (Moravcsik, 2008, 157. o.).

Moravcsik több írásában is látható (kár)örömmel reflektált az egyelöre nem realizálódott realista jövendölésekre (Moravcsik, 2009b). A(z új) liberális nemzetközi kapcsolatok elméletére építve egészen odáig ment el, hogy az erösödő Európa nemhogy veszítene jelentőségéből a 21. században az USA-val és Ázsiával való vetélke- 
Az eurózóna (lehetséges) szétesésének értelmezései az államközpontú...

désben, hanem az USA mellett Európa lehet az új világrend másik stabil bástyája. „A világ kétpólusú, és valószínűleg az is marad a belátható jövőben, amint a világ egyre interdependensebb, hálózatosabb és a nyílt rivalizálástól szabaddá válik. Európa a csöndes szuperhatalom" (Moravcsik, 2009b, 407. o.). Meggyőződése, hogy az Európát terhelő krízisek (brexit, migrációs válság, orosz-ukrán konfliktus, megszorítások stb.) sem mérsékelték érdemben az EU befolyását a globális erőtérben. A legfontosabb formális intézmények - ideértve a közös agrárpolitikát (KAP), az egységes piacot, a kereskedelempolitikát, a segélyezést stb. - érintetlenek maradtak; ezek az európai kontinens fejlődésének és erejének tartóoszlopai.

Legújabban pedig olyan láthatatlan szuperhatalomként hivatkozik az Európai Unióra, amely a különféle válságai ellenére a világgazdaság és a világpolitika meghatározó tényezője marad (Moravcsik, 2017a). Kiemeli Európa civil erejét, ami legalább olyan fontos, mint az USA hadászati potenciálja. Míg egy évszázada valóban a hadászati erő adta a hatalom legfőbb forrását, mára ez megváltozott. Az EU mint civil hatalom ereje egyebek mellett abból származik, hogy képes olyan vonzó multilaterális intézményeket kreálni, amelyekhez mások is szívesen csatlakoznak. Rámutat, hogy ma is sorban állnak a jelentkezésre váró tagok az EU-ba.

A szuperhatalmi pozíció azonban továbbra sem jelenti, hogy valamifajta szuverén szuperállam jönne létre Európában, és erre nincs is szükség - véli Moravcsik [2008, 2009, 2012]. Vallja, hogy tovább folytatódhat az EU mélyülése, ám e folyamat nem a föderális Európa irányában történő elmozdulást jelenti. A meghatározó, fő szereplök továbbra is az államok maradnak, amelyek csak annyi szuverenitásról hajlandók lemondani, amennyi feltétlenül szükséges. „Soha sem fog megvalósulni egy teljes mértékben föderális Európa. De a stabil alkotmányos alapok növekvően tiszta mandátumán belül Európa reagálni fog a mind erőteljesebben interdependenssé váló világ kihívásaira" (Moravcsik, 2012, 68-69. o.).

\section{Következtetések}

Miközben az integrációnak könyvtárnyi irodalma van, addig a dezintegrációról alig találni valamit (Zielonka, 2011). Holott az eurózóna válsága és vele a grexit lehetősége, vagy a nagy-britanniai kilépés mind azt mutatják, hogy hatvan évvel az Európai Gazdasági Közösség megalakulása után ideje a dezintegráció lehetőségét is komolyan venni. 
Az a néhány tanulmány, amely a témakörben napvilágot látott, jellemzően a már létező integrációs és nemzetközi kapcsolatokat áttekintő elméleteket próbálja feje tetejére állítani, és ily módon tesztelni azok használhatóságát. Webber [2014] alapján láttuk, hogy a dezintegráció egyszerre jelentheti (1) bizonyos tagállamok kilépését, vagy a közös politikákból való tartós kimaradását (horizontális dezintegráció), (2) a nemzetek feletti szervezetek gyengülését (vertikális dezintegráció), illetve (3) a tagállami szuverenitás visszaerösödését és a közös politikák szükülését (szektorális dezintegráció). Miközben a kontinens keleti és déli szegleteiben jelentkezők sora vár arra, hogy bebocsátást kapjon az EU-ba, 2016. június 23-án megtörtént az, ami korábban elképzelhetetlennek tünt: egy tagállam a kilépés mellett voksolt, precedenst teremtve ezzel az unióban a horizontális dezintegrációra. Minden mértékadó forrás azt bizonyítja, hogy mind rövid, mind pedig hosszú távon mindkét félnek jóléti veszteséget okoz Nagy-Britannia kilépése (Halmai, 2018, Losoncz, 2017). Nem valószínü, hogy a brit távozást más államok kilépése követné a közeli jövőben, mert jelenleg nincs vonzóbb alternatíva, ideértve az önállóságot is (Vollard, 2018). De mostanra a grexit is lekerült a napirendröl, és bár több más tagállammal kapcsolatban is felvetődött - legalábbis a napi sajtó szintjén - az euróövezetből való kilépés lehetősége, egyre valószínütlenebb ez a szcenárió. ${ }^{12}$ A vertikális integráció kapcsán az a paradoxon érdemel figyelmet, amely szerint a válságot követő időszakban úgy mélyült az integráció, hogy közben az olyan kormányközi szervek, mint az Európai Tanács vagy az Európai Unió Tanácsa tovább növelték befolyásukat (Puetter, 2012). Abban ugyanakkor jelenleg nincs konszenzus a szakirodalomban, hogy a szupranacionális intézmények erősödését, avagy gyengülését hozta-e a válság, illetve a válságrendezés. (A két ellentétes nézőpont kapcsán lásd: Bickerton-Hodson-Puetter [2015], illetve Bauer-Becker [2014]). A szektorális integráció tekintetében pedig a differenciálódás mind egyértelmübb jelei mutatkoznak, ezt rendkívüli módon aláhúzza a bankunió kiteljesedése. Habár léteznek eltérő érdekek, ám a felek közös akarata láthatóan az eurózóna egyben tartása, és ennek eszköze a pénzügyi integráció teljessé tétele (Csaba, 2018). Ez pedig azt igazolja, hogy csak azért, mert az optimális valutaövezetek elmélete alapján nem lett volna indokolt útjára bocsátani az eurót, még nem jelenti azt, hogy most fel kellene adni. Az exit költsége ugyanis mostanra magasabb, mint a bennmaradás költsége.

${ }_{12}$ Az egyik legmeglepőbb ilyen lépés Finnországban történt. Előbb 2015-ben, majd 2016-ban vetődött fel, hogy az eurótagságról (illetve később már az EU-tagságról is) népszavazást kellene tartani, mert akkor végre le lehetne értékelni az újra bevezetésre kerülő finn valutát, ami erősítené az exportot. A kilépést, ami végül támogatottság hiányában elbukott, a populista Finnek Pártja kezdeményezte. 
Az eurózóna (lehetséges) szétesésének értelmezései az államközpontú...

Ezzel együtt is tény, hogy létezik egyfajta dezintegrációs nyomás az EU-ban, ami - egyéb okok mellett - az eurózóna szerkezeti hiányosságaiból, feszültségeiből is táplálkozik. Az euró feladását támogató erők (és ideák) meghatározó forrása és hajtóereje a belső politika az egyes tagállamokban. A korábbi integrációt támogató és széles körben osztott konszenzust mára e konszenzus hiánya váltotta fel (HoogheMarks, 2008). Míg korábban a tagállami színtéren marginalizált szereplők voltak az EU- és euróellenes csoportok és pártok, mostanra befolyásoló tényezővé erősödtek. És ez nemcsak a válsággal sújtott Görögországra igaz, ahol a szélsőségesen populista Syriza 2015-ben kormányra került, hanem Olaszországra (ahol idöközben szintén populista hatalomátvétel történt), Spanyolországra, de még az integráció motorjának számító Németországra is.

Az államközpontú elméletek gyengesége éppen ebben ragadható meg. E tendenciákkal és az integrációszkeptikus hangokkal és általában is a hazai politika hatásaival az egyes államközpontú elméletek nem foglalkoznak. A realizmus (pontosabban a neorealizmus) még érintőlegesen sem próbálkozik ezzel. A neoliberális institucionalizmus ugyan fel- és elismeri a belső politika fontosságát (Keohane, 1998, Katzenstein-Keohane-Krasner, 1998), de az elmélet igazán soha nem tette magáévá a hazai színtér tanulmányozását. A liberális kormányköziség elmélete jutott legközelebb a belső politikához. Nevében a liberális jelző arra utal, hogy a preferenciaformálás is szerves része a nagy elméletnek (Moravcsik, 1998). Csakhogy a preferenciákat még ez esetben sem befolyásolja maga az integráció folyamata. ${ }^{13}$

Az államközpontú elméletek így leginkább a tagállamok közötti törésvonalak és alkuk tanulmányozásában segíthetik az érdeklődőket; annak megértésében például, hogy a válságrendezés hasznait és különösképpen költségeit miként osztják el egymás között a felek. Ez természetesen egyáltalán nem kevés, hiszen az elmúlt tíz esztendő egyik legnagyobb kihívása éppen az volt, hogy az európai gazdasági integráció folyamatát többé nem lehet pusztán szabályozási kérdésként értelmezni, az legalább annyira elosztási kérdés is. Az elosztási kérdések természetüknél fogva konfliktusokkal terheltek. A konfliktusok pedig - a felismert közös érdek és célok hiányában - ellenségeskedéshez, végső esetben szakításhoz, széteséshez vezethetnek. Az eurózóna egyben tartása akkor remélhető, ha a felek felismerik közös érdeküket és felvállalják a kollektív cselekvéseket - azok költségeivel együtt. E folyamat kimenete azonban nehezen volna most még megjósolható.

${ }^{13}$ A belső politika fontosságát taglalja mások mellett Börzel-Risse [2018], akik egyben az integrációelméletek kritikáját is adják. 


\section{Hivatkozások}

Aslett, Kevin - Caporaso, James [2016]: Breaking up is hard to do: Why the Eurozone will survive. Economies, Vol. 4., No. 4., 1-16. o.

Bauer, Michael W. - Becker, Stefan [2014]: The unexpected winner of the crisis: The European Commission's strengthened role in economic governance. Journal of European Integration, Vol. 36., No. 3., 213-229. o.

Beck, Ulrich [2014]: The reflexive modernization of democracy. In: Gagnon, Jean-Paul (szerk.): Democratic theorists in conversation: Turns in contemporary thoughts. Palgrave MacMillan, Basingstoke, $85-100$. o.

Benczes István - Rezessy Gergely [2013]: Kormányzás Európában: Trendek és törésvonalak. Pénzügyi Szemle, 58. évf., 2. sz., 136-150. o.

Bickerton, Christopher - Hodson, Dermot - Puetter, Uwe [2015]: The new intergovernmentalism: European integration in the post-Maastricht era. Journal of Common Market Studies, Vol. 53., No. 4., 703-722. o.

Bordo, Michael D. - Jonung, Lars [2000]: Lessons for EMU from the history of monetary unions. Institute for Economic Affairs, London.

Börzel, Tanja - Risse, Thomas [2018]: From the euro to the Schengen crises: European integration theories, politicization, and identity politics. Journal of European Public Policy, Vol. 25., No. 1., 83-108. o.

Bulmer, Simon - Paterson, William E. [2013]: Germany as the EU's reluctant hegemon? Of economic strength and political constraints. Journal of European Public Policy, Vol. 20., No. 10., 1387-1405. o.

Cohen, Benjamin [1998]: The geography of money. Cornell University Press, Ithaca.

Cohen, Benjamin [2008]: International political economy: An intellectual history. Princeton University Press, Princeton.

Collard-Wexler, Simon [2006]: Integration under anarchy: Neorealism and the European Union. European Journal of International Relations, Vol. 12., No. 3., 397-432. o.

Crawford, Beverly [2009]: The normative power of a normal state: Power and revolutionary vision in Germany's post-wall foreign policy. Paper prepared for the Conference: „Legacies of German Unification: Twenty Years of German Unity”. University of Washington, Center for West European Studies, 20. November.

Csaba László [2018]: Tökepiaci unió vagy szabadságharc? Közgazdasági Szemle, 65. évf., 5. sz., 484-498. o.

Deudney, Daniel - Ikenberry, G. John [1999]: Realism, structural liberalism, and the Western order. In: Kapstein, Ethan B. - Mastanduno, Michael (szerk.): Unipolar politics: Realism and state strategies after the cold war. Columbia University Press, New York, 103-137. o.

Dornbusch, Rudiger [2001]: The euro controversy. MIT Department of Economics Editorial.

Eichengreen, Barry [1996a]: EMU: An outsider's perspective. Papers, 96/26. University College, Dublin.

Eichengreen, Barry [1996b]: Globalizing capital: A history of the international monetary system. Princeton University Press, Princeton.

Eichengreen, Barry [2010]: The break-up of the euro area. In: Alesina, Alberto - Giavazzi, Francesco (szerk.): Europe and the euro. The University of Chicago Press, 11-51. o.

Eppler, Annegret - Anders, Lisa - Tuntchew, Thomas [2016]: Europe's political, social, and economic (dis-)integration: revisiting the elephant in times of crisis. IHS Political Science Series, Working Paper, No. 143., Bécs.

Fabbrini, Sergio [2016]: From consensus to domination: The intergovernmental union in a crisis situation. Journal of European Integration, Vol. 38., No. 5., 587-599. o. 
Feldstein, Martin [1997]: The political economy of the European economic and monetary union: Political sources of an economic liability. Journal of Economic Perspectives, Vol. 11., No. 4., 23-42. o.

Feldstein, Martin [2010]: Let Greece take a euro-zone holiday. Financial Times, 2010. február 16. Letölthető: http://www.ft.com/intl/cms/s/0/72214942-1b30-11df-953f-00144feab49a.html.

Frankel, Benjamin [1996]: Restating the realist case: An introduction. In: Frankel, Benjamin (szerk.): Realism: Restatements and renewal. Frank Cass and Co, London, ix-xx. o.

Frankel, Jeffrey A. - Rose, Andrew [1998]: The endogeneity of the optimum currency area Criteria. The Economic Journal, Vol. 108., No. 449., 1009-1025. o.

Gilpin, Robert [1975]: US power and the multinational corporation. Basic Books, New York.

Gilpin, Robert [1987]: The political economy of international relations. Princeton University Press.

Grieco, Joseph M. [1995]: The Maastricht Treaty, Economic and Monetary Union and the neo-realist research programme. Review of International Studies, Vol. 21., No. 1., 21-40. o.

Grieco, Joseph M. [1996]: State interests and institutional rule trajectories: A neorealist interpretation of the Maastricht Treaty and European Economic and Monetary Union. Security Studies, Vol. 5., No. 3., 261-306. o.

Győrffy Dóra [2017]: Görögország a monetáris unióban: A kilépés hiábavalósága. Magyar Tudomány, 178. évf., 1. sz., 24-33. o.

Hall, Peter A. [2012]: The economics and politics of the euro crisis. German Politics, Vol. 21., No. 4., 355-371. o.

Halmai Péter [2018]: A brexit lehetséges gazdasági hatásai. Európai Tükör, megjelenés alatt.

Henning, Randall - Kessler, Martin [2012]: Fiscal federalism: US history for architects of Europe's fiscal union. Peterson Institute for International Economics, Working Paper, No. 1.

Hoffmann, Stanley [1966]: Obstinate or obsolote? The fate of the nation-state and the case of Western Europe. Daedalus, Vol. 95., No. 3., 862-915. o.

Holzinger, Katharina - Schimmelfennig, Frank [2012]: Differentiated integration in the European Union: Many concepts, sparse theory, few date. Journal of European Public Policy, Vol. 19., No. 2., 292-305. o.

Hooghe, Liesbet-Marks, Gary [2008]: A postfunctionalist theory of European integration: From permissive consensus to constraining dissensus. British Journal of Political Science, Vol. 39., No. 1., 1-23. o.

Janning, Josef - Möller, Almut [2016]: Leading from the centre: Germany's new role in Europe. European Council on Foreign Relations. Policy Brief, July, London.

Jones, Erik [2018]: Towards a theory of disintegration. Journal of European Public Policy, Vol. 25., No. 3., 440-451. o.

Jonung, Lars - Drea, Eoin [2010]: It can't happen. It's a bad idea. It won't last. Econ Journal Watch, Vol. 7., No. 1., 4-52. o.

Katzenstein, Peter J. - Keohane, Robert O. - Krasner, Stephen D. [1998]: International Organization and the study of world politics. International Organization, Vol. 52., No. 4., 645-685. o.

Keohane, Robert [1984]: After hegemony: Cooperation and discord in the world political economy. Princeton University Press.

Keohane, Robert O. [1993]: Institutionalist theory and the realist challenge after the cold war. In: Baldwin, D. A. (szerk): Neo-realism and neo-liberalism: The contemporary debate. Columbia University Press, New York, 269-300. o.

Keohane, Robert O. [1998]: International institutions: Can interdependence work? Foreign Policy, Vol. 110., Spring, 82-96. o.

Keohane, Robert-Martin, Lisa L. [1995]: The promise of institutionalist theory. International Security, Vol. 20., No. 1., 39-51. o. 
Keohane, Robert-Martin, Lisa L. [2003]: Institutional theory as a research program. In: Elman, Colin - Elman, Miriam (szerk.): Progress in international relations theory. Cambridge University Press, 71-107. o.

Keohane, Robert O. - Nye, Joseph [1993]: Introduction: The end of the cold war in Europe. In: Keohane, Robert O. - Nye, Joseph - Hoffmann, Stanley (szerk.): After the cold war: International institutions and state strategies in Europe 1989-91. Harvard University Press, Cambridge, Mass., 1-19. o.

Kindleberger, Charles [1973]: The world in depression, 1929-1939. University of California Press, Berkeley.

Krugman, Paul [2013]: Revenge of the optimum currency area. In: Acemoglu, Daron - Parker, Jonathan - Woodford, Michael (szerk.): NBER Macroeconomics Annual 2012. Vol. 27. University of Chicago Press, 439-448. o.

Krugman, Paul [2016]: When virtue fails. The New York Times, 2016. június 17.

Kundnani, Hans [2015]: The paradox of German power. Oxford University Press.

Loriaux, Michael [1999]: Realism and reconciliation: France, Germany, and the European Union. In: Kapstein, Ethan B. - Mastanduno, Michael (szerk.): Unipolar politics: Realism and state strategies after the cold war. Columbia University Press, New York, 354-384. o.

Losoncz Miklós [2017]: Az Egyesült Királyság kilépése az EU-ból és az európai integráció. Budapesti Gazdasági Egyetem.

Mearsheimer, John J. [1990a]: Back to the future: Instability in Europe after the cold war. International Security, Vol. 15., No. 1., 5-56. o.

Mearsheimer, John J. [1990b]: Why we will soon miss the cold war? The Atlantic Monthly, Vol. 266., No. 2., 35-50. o.

Mearsheimer, John J. [2010]: Why is Europe peaceful today? European Political Science, Vol. 9., No. 3., 387-397. o.

Merkel, Angela [2010]: Merkel warns of Europe's collapse. Spiegel Online. Letölthetö: http://www. spiegel.de/international/germany/merkel-warns-of-europe-s-collapse-if-euro-fails-so-will-theidea-of-european-union-a-694696.html

Mérö Katalin - Piroska Dóra [2017]: Az Európai Bankunió reformja: a makroprudenciális felhatalmazások rendszerének újragondolása a kelet- és közép-európai országok szemszögéböl. Külgazdaság, 61. évf., 9-10. sz., 3-29. o.

Moravcsik, Andrew [1998]: The choice for Europe: Social purpose and state power from Messina to Maastricht. Cornell University Press, Ithaca, New York.

Moravcsik, Andrew [2008]: The European constitutional settlement. World Economy, Vol. 31., No. 1., 158-183. o.

Moravcsik, Andrew [2009a]: Why Europe is stronger than ever? Newsweek, US edition, 2009. július 31.

Moravcsik, Andrew [2009b]: Europe: The quiet superpower. French Politics, Vol. 7., No. 3/4., 403-422. o.

Moravcsik, Andrew [2012]: Europe after the crisis. Foreign Affairs, Vol. 91., No. 3., 54-68. o.

Moravcsik, Andrew [2017a]: Europe is still a superpower. Foreign Policy, 2017. április 13.

Moravcsik, Andrew [2017b]: Moravcsik interview, part I: Britain is the exception to the rule. Interjú, készítette: Pavol Szalai. EurActiv, 2017. március 29. Letölthető. https://www.euractiv.com/section/ uk-europe/interview/moravcsik-interview-part-i-britain-is-the-exception-to-the-rule/

Morgenthau, Hans J. - Thompson, Kenneth W. [1985]: Politics among nations. McGraw-Hill, New York.

Morisse-Schilbach, Melanie [2011]: “Ach Deutschland!” Greece, the euro crisis, and the costs and benefits of being a benign hegemon. Internationale Politik und Gesellschaft, Vol. 14., No. 1., 28-41. o.

Myrdal, Gunnar [1956]: An international economy: Problems and prospects. Harper and Brothers, New York. 
Paterson, William [2012]: A contested Franco-German duumvirate. In: Hayward, Jack - Wurzel, Rüdiger (szerk.): European disunity: between sovereignity and solidarity. Palgrave Macmillan, Basingstoke, 235-251. o.

Pedersen, Thomas [1998]: Germany, France, and the integration of Europe: A realist interpretation. Printer, London.

Polányi, Karl [1944/2001]: The great transformation: The political and economic origins of our time. Beacon Press.

Puetter, Uwe [2012]: Europe's deliberative intergovernmentalism: The role of the Council and European Council in EU economic governance. Journal of European Public Policy, Vol. 19., No. 2., 161-78. o.

Rockoff, Hugh [2000]: How long did it take the United States to become an optimal currency area? NBER Historical Working Paper, 124. sz.

Rodrik, Dani [2010]: Thinking the unthinkable in Europe. Project Syndicate, december 10. Letölthetö: http://www.project-syndicate.org/commentary/thinking-the-unthinkable-in-europe.

Rosato, Sebastian [2010]: Europe United: Power Politics and the Making of the European Community. Cornell University Press, Ithaca.

Sadeh, Tal -Verdun, Amy [2009]: Explaining Europe's monetary union: A survey of the literature. International Studies Review, Vol. 11., No. 2., 277-301. o.

Schild, Joachim [2010]: Mission Impossible? The potential for Franco-German leadership in the enlarged EU. Journal of Common Market Studies, Vol. 48., No. 5., 1367-1390. o.

Schimmelfennig, Frank [2015]: Liberal intergovernmentalism and the euro area crisis. Journal of European Public Policy, Vol. 22., No. 2., 177-195. o.

Stone, Alec [1994]: What is a supranational constitution? An essay in international relations theory. The Review of Politics, Vol. 56., No. 3., 441-474. o.

Streeck, Wolfgang [2015]: German hegemony: Unintended and unwanted. Eurozine, 2015. szeptember 23. Letölthetö: http://www.eurozine.com/german-hegemony-unintended-and-unwanted/

Vigvári Gábor [2016]: Trilemmából dilemma: Politikai gazdaságtani gondolatok az Európai Unió jövőjéröl az elmúlt évek válságai alapján. Köz-gazdaság, 11. évf., 3. sz., 281-293. o.

Vollaard, Hans [2014]: Explaining European disintegration. Journal of Common Market Studies, Vol. 52., No. 5., 1142-1159. o.

Vollaard, Hans [2018]: European disintegration: A search for explanation. Palgrave Macmillan, London.

Waltz, Kenneth [1979]: Theory of international politics. McGraw Hill, New York.

Waltz, Kenneth [1993]: The emerging structure of international politics. International Security, Vol. 18., No. 2., 45-73. o.

Webb, Michael C. - Krasner, Stephen D. [1989]: Hegemonic stability theory: An empirical assessment. Review of International Studies, Vol. 15., No. 2., 183-198. o.

Webber, Douglas [2014]: How likely is it that the European Union will disintegrate? A critical analysis of competing theoretical perspectives. European Journal of International Relations, Vol. 20., No. 2., 341-365. o.

Zielonka, Jan [2011]: Europe: A plan for disintegration. Le Monde Diplomatique, szeptember 13.

Zielonka, Jan [2015]: Disintegration theory: International implications of Europe's crisis. Politics \& Diplomacy, tél/tavasz, 51-60. o. 